Bangladesh J. Bot. 47(4): 969-974, 2018 (December)

\title{
BUD POPULATION CHARACTERISTICS OF PHYLLOSTACHYS PRAECOX 'PREVERNALIS' UNDER DIFFERENT MULCHING CULTIVATION PERIODS
}

\author{
Guibin Gao ${ }^{1}$, Zhizhuang Wu ${ }^{1}$, Wen Xing ${ }^{1}$, XiaOping Zhang, \\ HaO ZHONG ${ }^{2}$ AND YANHONg PAN ${ }^{2}$
}

China National Bamboo Research Center, 310012, Hangzhou, Zhejiang, P.R. China

Keywords: Phyllostachys praecox, Mulching cultivation, Human disturbance, Bud bank, Bud population, Bud flow

\begin{abstract}
A study of the response of the bud population in bamboo forests to intensive human disturbance revealed the regulation potential of the bud bank for the regeneration of bamboo populations under mulching cultivation. Differences in bud bank composition and budflow characteristics of Phyllostachys praecox Z. D. Chu et C. S. Chao 'Prevernalis' S. Y. Chen et C. Y. Yao were compared to explore the impact of highly intensive management on the characteristics of bamboo forest bud populations under different mulching cultivation periods. The results indicated that the soil depth at which the bud bank of bamboo forests grew decreased significantly due to intensive management during mulching cultivation. The longer the mulching time, the smaller the total number of buds, the greater the bud mortality, and the weaker the bud-input and bud-output abilities. After long-term mulching, the rates of bamboo forest bud-storage and bud dormancy decreased, output and mortality rates increased, and the bud-input rate increased, although the maximum bud-input rate was smaller than that for un-mulched areas. It was found that mulching cultivation of bamboo forests broke rhizome lateral-bud dormancy, resulting in high-intensity bud-output. Therefore, restoration of declining bamboo populations demands the increase of bud-input and the reduction of bud-output, in order to promote sustainable management of bamboo forests.
\end{abstract}

\section{Introduction}

The bud bank of plants plays an important role in the development of the population, maintenance of productivity, and coping with adverse environment conditions (Benson et al. 2004, Hartnett et al. 2006, Dalgleish and Hartnett 2009) especially in extreme habitats or after extensive disturbance. Under these circumstances, plants derived from the bud bank, which can be seen as a potential population, are able to complete vegetation renewal through vegetative reproduction (Vesk and Westoby 2004). The initial characteristics of the bud bank of perennial plants are determined by the genetic characteristics of the species itself (Russell et al. 2015); however, the influence of environmental factors on the growth and development characteristics of the bud population, such as shading treatment, growth season, and soil nutrients, could lead to differences in the structure and number of buds in the bud bank (Hogg and Lieffers 1991, Klimes 2007).

In bamboo forests, mulching of the shoot has produced great economic benefits, but the bamboo plant is severely stressed by human disturbance, which seriously affects the physiological activities of bamboo (Xu et al. 2017). Phyllostachys praecox Z. D. Chu et C. S. Chao 'Prevernalis' S. Y. Chen et C.Y. Yao is a fine, small diameter bamboo species grown for its shoots, and which is seriously degraded by mulching (Jiang et al. 2002). So far a few reports on the characteristics of the bud bank of this bamboo forest and the regeneration of its population under high intensity human

\footnotetext{
"Author for correspondence: <zxpyg2016@126.com>. ${ }^{1}$ National Long-term Observation and Research Station for Forest Ecosystem in Hangzhou-Jiaxing-Huzhou Plain, Zhejiang, 310012, Hangzhou, Zhejiang, P.R. China. ${ }^{2}$ Key Laboratory of High Efficient Processing of Bamboo of Zhejiang Province, 310012, Hangzhou, Zhejiang, P.R. China.
} 
interference due to mulching cultivation are available. Therefore, the bud bank composition and bud flow characteristics of Phyllostachys praecox 'Prevernalis' under different mulching periods were studied. The present study aimed to clarify the response mechanism of the structure and function of bud banks to human disturbance and to reveal the regulatory potential of a bud bank on the structure and regeneration of a bamboo population, by exploring the effect of highly intensive management on the characteristics of bud population, and thus, provide the basis for the restoration of degraded bamboo forest populations.

\section{Materials and Methods}

This study was conducted in a bamboo forest of Phyllostachys praecox 'Prevernalis' located in Yuhang District $\left(30^{\circ} 43^{\prime} \mathrm{N}\right.$ and $\left.120^{\circ} 30^{\prime} \mathrm{E}\right)$, Hangzhou, Zhejiang Province, China. Bamboo forests that have been managed for different mulch cultivation periods with similar site conditions and management levels were selected and marked, namely: control (mulching for 0 years), cumulative mulching for 4 years, cumulative mulching for 8 years, and cumulative mulching for 12 years. Mulching of the bamboo forests in the sampling area was done with a $10 \mathrm{~cm}$ layer of wheat bran fermentation and a $15 \mathrm{~cm}$ thick rice husk insulation layer.

In November 2017, three $100 \mathrm{~m}^{2}$ sample quadrates (3 replications) were randomly selected within each mulching period plot. In each sample quadrate, 3 small quadrates of $1 \mathrm{~m}^{3}$ were randomly marked, so there were $9,1 \mathrm{~m}^{3}$ small quadrates ( 9 replications) in each sampling plot. The soil depth was stratified at $10 \mathrm{~cm}$ intervals; the rhizomes were dug out, washed and dried. Rhizomes were divided into 2 types according to age: 1 -year old and $\geq 2$-year-old rhizomes. The number of dormant buds and dead buds were counted. From December, 2017 to April, 2018 the number of germinated bamboo shoots and the soil depth of bamboo shoot growth were counted daily in each sampling quadrate. The total bud storage was defined as the sum of dormant buds of 1-year old, and $\geq 2$-year-old rhizomes; bud-input was defined as the number of dormant buds of 1-year old rhizomes; bud-output was defined as the number of germinating buds on $\geq 2$-year-old rhizomes; number of dormant buds was defined as the number of dormant buds on $\geq 2$-year-old rhizomes; bud mortality was defined as the number of dead buds on 1-year old, and $\geq 2$-year-old rhizomes. Bud storage rate, bud-input rate, bud-output rate, bud-dormancy rate, and bud-mortality rate were the quotients of bud storage, bud-input, bud-output, bud-dormancy, bud-mortality number with the total bud number (the sum total of the number of lateral buds of 1 -year old and $\geq 2$-year-old rhizomes) respectively. The total lateral bud number on bamboo rhizomes was taken as the bud bank; the ratio of the bud bank composition to the bud bank was regarded as the bud flow.

Data means, and standard deviations were calculated in Excel (Microsoft, Redmond, WA, USA). The data were compared using a one-way analysis of variance and Student-Newman-Keuls testin SPSS 19.0 (IBM, Armonk, NY, USA). Unless otherwise specified, differences were significant at $\mathrm{p}<0.05$.

\section{Results and Discussion}

Fig. 1 shows that bud storage of the un-mulched plots was mainly distributed between 20 and $40 \mathrm{~cm}$ within the soil profile, while bud storage in plots where mulching was done, was found distributed in the $10-30 \mathrm{~cm}$ soil layer. Mulching cultivation decreased bud storage. Total bud storage peaked in 4-year mulching plots, whereas it was lowest in 12-year mulching plots, there being a significant difference between the two $(\mathrm{p}<0.05)$, indicating that the longer the mulching, the lower the bud storage. As shown in Fig. 2, the bud-input number of bamboo forests was mainly distributed within the $10-20 \mathrm{~cm}$ soil layer produced by mulching cultivation. Total bud-input number of 12-year mulching plots was the lowest, and significantly different from the other 
mulching plots under study $(\mathrm{p}<0.05)$; although there was no significant difference among the former $(\mathrm{p}>0.05)$, suggesting that the longer the mulching period, the less conductive the bamboo was to bud-input.

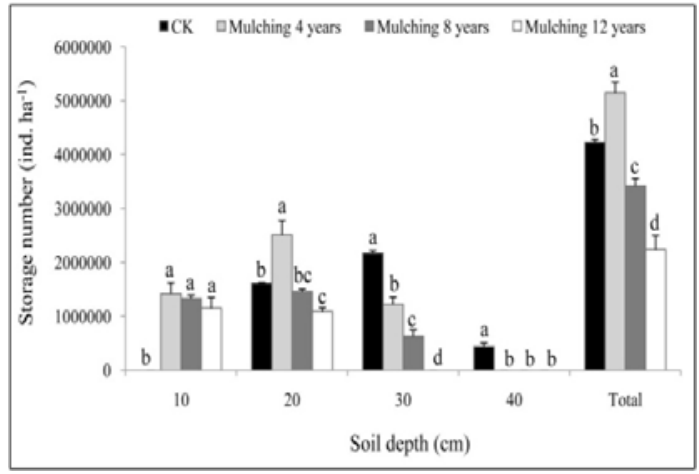

Fig. 1. Bud storage number of different soil depth. From a to $\mathrm{d}$, the significance of the difference gradually strengthened $(\mathrm{p}<0.05)$.

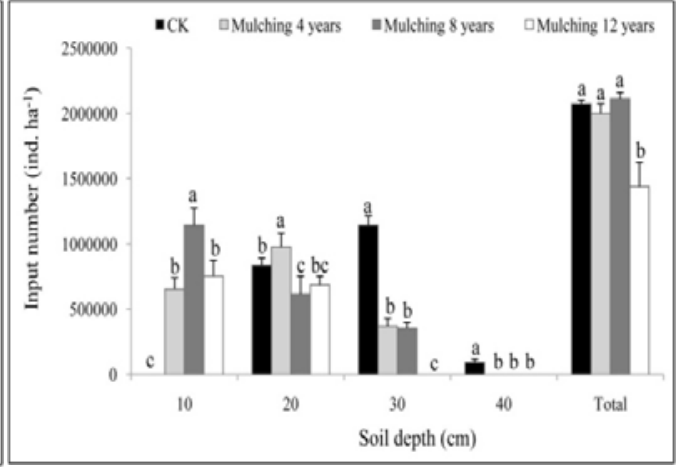

Fig. 2. Bud input number of different soil depth. From a to $c$, the significance of the difference gradually strengthened $(\mathrm{p}<0.05)$.

Bud-output of no-mulching plots mainly originated from $30 \mathrm{~cm}$ soil depth (Fig. 3), but the bud-output of the mulching plots, was mainly derived from the $10-20 \mathrm{~cm}$ soil layer. Total bud output number of mulching plots was significantly higher than that of no-mulching plots $(\mathrm{p}<0.05)$; as the mulching period increased, the total bud-output number decreased significantly $(p<0.05)$, indicating that bamboo mulching could promote bud-output, but as the mulching time was extended, the promoting effect became significantly reduced. The soil-depth of dormant buds in mulching bamboo forests decreased (Fig. 4). Total dormant bud number in 4-year mulching plots was the highest among all the treatments. The number of dormant buds decreased sharply with the increase of mulching period, and long-term mulching was not conductive to the survival of the dormant buds.

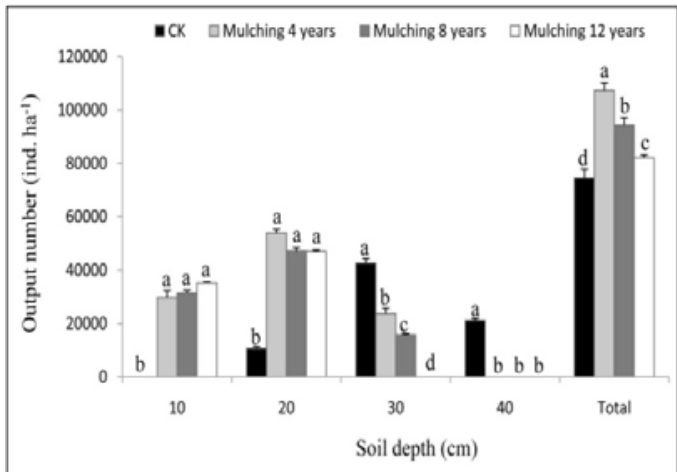

Fig. 3. Bud output number of different soil depth. From a to $\mathrm{d}$, the significance of the difference gradually strengthened $(\mathrm{p}<0.05)$.

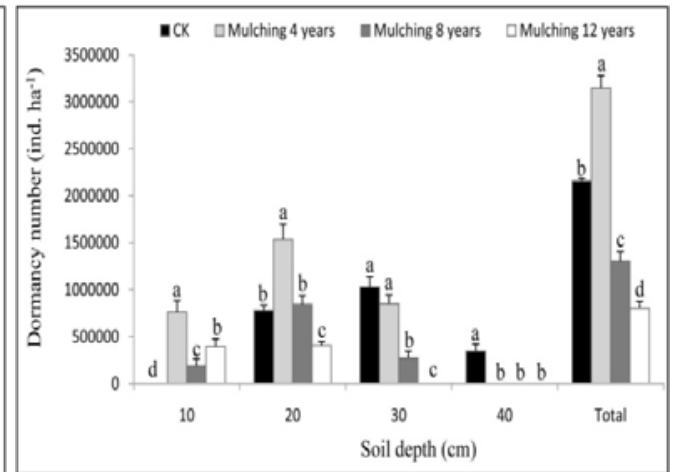

Fig. 4. Bud dormancy number of different soil depth. From a to $d$, the significance of the difference gradually strengthened $(\mathrm{p}<0.05)$.

Total dead-bud number in mulching plots was significantly higher than in no-mulching plots ( $p$ $<0.05$ ) (Fig. 5), indicating that a large number of bamboo rhizome lateral buds died because of mulching cultivation. The total bud number at each soil depth in 4-year mulching plots was significantly higher than in any other plots $(\mathrm{p}<0.05)$ (Fig. 6). The longer the mulching time, the 
smaller the total bud number in the bamboo forest $(\mathrm{p}<0.05)$, indicating that mulching resulted in the decay of the bamboo buds.

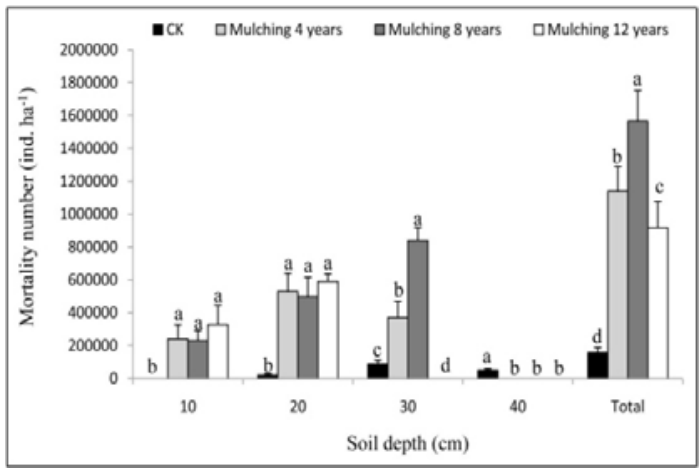

Fig. 5. Bud mortality number of different soil depth. From a to $d$, the significance of the difference gradually strengthened $(\mathrm{p}<0.05)$

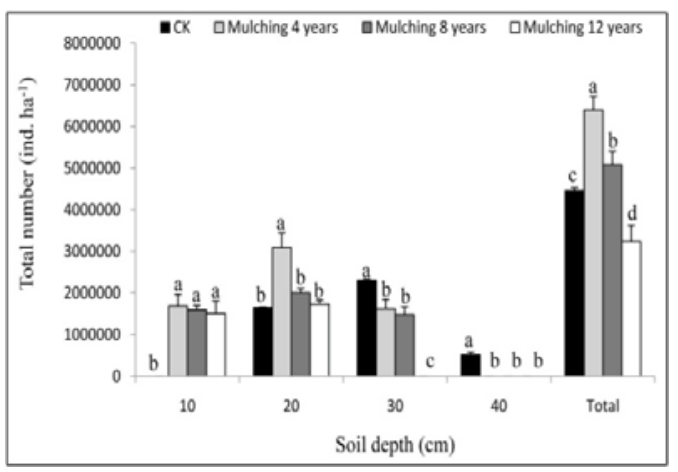

Fig. 6. Total bud number of different soil depth. From a to $d$, the significance of the difference gradually strengthened $(\mathrm{p}<0.05)$.

The development of bamboo populations is mainly based on asexual reproduction, and the rhizome lateral buds are the main source of the formation of bamboo modules, so they are important material basis of the recovery of declining bamboo populations. Previous studies have shown (Ott and Hartnett 2015, Qian et al. 2017) that plant bud bank usually shows a degree of adaptability to environmental changes brought about by different external ecological factors and various interfering factors. In this study, it was found that mulching cultivation associated with highly intensive management caused the bamboo bud bank to rise obviously in the soil; the longer the mulching time, the smaller the total bud number, the greater the bud mortality numbers, and the weaker the bud-input and bud-output ability. The residual mulching materials of bamboo forests easily produce fertilizing effects after mineralization, and bamboo rhizome has a strong tropism towards fertile soil (Xu et al. 2017), which should be an important reason for the rising of bamboo bud bank. Therefore, residual mulching materials should be cleaned with time. After long-term mulching, soil acidification is a serious problem (Gui et al. 2013) that leads to significant changes in soil fertility (Jiang et al. 2006, Guo et al. 2014) whereby, soil microbial structure is obviously changed (Xu et al. 2008). This clearly explains the decrease of bud bank and the increase of bud mortality numbers observed in this study. Therefore, the restoration of degraded soils is the basic condition for the restoration of the declining bamboo forests.

As shown in Table 1, at $10 \mathrm{~cm}$ soil depth, the bud storage rate of CK was 0. Further, in the $20-40 \mathrm{~cm}$ soil layer, the storage rate decreased significantly with the increase of mulching period $(\mathrm{p}<0.05)$. Total storage rate decreased with the increase of the mulching period, but the difference between 8- and 12-year mulching plots was not significant $(\mathrm{p}>0.05)$. This indicated that long-term mulching led to a decrease in the storage rate of the rhizome lateral buds of the bamboo forest. Except for the zero bud-input rate of CK at $10 \mathrm{~cm}$ soil depth, all bud-input rate values in mulching plots, after the same mulching period, decreased with increasing soil depth. This indicated that the deeper the soil depth, the lower the bud-input rate.

The longer the mulching time, the higher the bud-output rate from the shallow soil layers of the bamboo forest. The total bud-output rate in the bamboo forest in this study showed an increasing trend with the increase of mulching period; further, the total bud-output rate in 12-year mulching plots was significantly higher than in any other mulching plots $(p<0.05)$, indicating that, the longer the duration of mulching, the higher the rate of bud-output, which reflected that bamboo forest 
resources had been intensively over exploited. Overall, the bud dormancy rate of bamboo forests with short mulching periods was higher than that of those with long mulching periods. This indicated that the longer the mulching period, the lower the bud dormancy rate in bamboo forests. The bud mortality rate of the same mulching period increased with soil depth, which showed that the deeper the soil depth, the higher the bamboo rhizome bud-mortality rate. Except for those plots where the bud mortality rate was 0 , bud mortality rate at different soil depths increased with increasing mulching period, with significant differences among them $(p<0.05)$. This showed that the longer the mulching time, the higher the bud mortality rate in bamboo forests.

Table 1. Bud flow of different soil depth.

\begin{tabular}{|c|c|c|c|c|c|}
\hline \multirow[t]{2}{*}{ Index } & \multirow{2}{*}{$\begin{array}{l}\text { Soil depth } \\
(\mathrm{cm})\end{array}$} & \multicolumn{4}{|c|}{ Mulching period } \\
\hline & & $\mathrm{CK}$ & 4 years & 8 years & 12 years \\
\hline \multirow{5}{*}{$\begin{array}{l}\text { Storage rate } \\
(\%)\end{array}$} & 10 & $0.00 \pm 0.00 \mathrm{c}$ & $84.21 \pm 2.74 \mathrm{a}$ & $83.70 \pm 3.09 \mathrm{a}$ & $76.30 \pm 4.32 b$ \\
\hline & 20 & $98.14 \pm 0.63 \mathrm{a}$ & $81.18 \pm 2.32 b$ & $73.01 \pm 4.48 \mathrm{c}$ & $63.19 \pm 1.25 \mathrm{~d}$ \\
\hline & 30 & $94.37 \pm 1.20 \mathrm{a}$ & $75.89 \pm 3.24 b$ & $42.06 \pm 3.07 \mathrm{c}$ & $0.00 \pm 0.00 \mathrm{~d}$ \\
\hline & 40 & $86.05 \pm 1.29 \mathrm{a}$ & $0.00 \pm 0.00 \mathrm{~b}$ & $0.00 \pm 0.00 \mathrm{~b}$ & $0.00 \pm 0.00 \mathrm{~b}$ \\
\hline & Total & $94.82 \pm 0.74 \mathrm{a}$ & $80.54 \pm 1.50 \mathrm{~b}$ & $67.37 \pm 1.51 \mathrm{c}$ & $69.24 \pm 2.35 \mathrm{c}$ \\
\hline \multirow{5}{*}{$\begin{array}{l}\text { Input rate } \\
(\%)\end{array}$} & 10 & $0.00 \pm 0.00 \mathrm{~d}$ & $38.90 \pm 1.61 \mathrm{c}$ & $71.66 \pm 6.24 \mathrm{a}$ & $50.08 \pm 3.32 b$ \\
\hline & 20 & $50.81 \pm 3.69 \mathrm{a}$ & $31.59 \pm 1.00 \mathrm{c}$ & $30.91 \pm 7.23 \mathrm{c}$ & $39.63 \pm 1.67 b$ \\
\hline & 30 & $49.67 \pm 3.42 \mathrm{a}$ & $22.95 \pm 2.89 \mathrm{~b}$ & $23.85 \pm 0.79 b$ & $0.00 \pm 0.00 \mathrm{c}$ \\
\hline & 40 & $18.60 \pm 6.47 \mathrm{a}$ & $0.00 \pm 0.00 \mathrm{~b}$ & $0.00 \pm 0.00 \mathrm{~b}$ & $0.00 \pm 0.00 \mathrm{~b}$ \\
\hline & Total & $46.48 \pm 0.69 \mathrm{a}$ & $31.28 \pm 0.49 \mathrm{c}$ & $41.66 \pm 1.63 \mathrm{~b}$ & $44.38 \pm 1.16 \mathrm{ab}$ \\
\hline \multirow{5}{*}{$\begin{array}{l}\text { Output rate } \\
(\%)\end{array}$} & 10 & $0.00 \pm 0.00 \mathrm{c}$ & $1.80 \pm 0.41 \mathrm{~b}$ & $1.98 \pm 0.17 \mathrm{ab}$ & $2.39 \pm 0.45 \mathrm{a}$ \\
\hline & 20 & $0.65 \pm 0.03 \mathrm{c}$ & $1.75 \pm 0.15 b$ & $2.35 \pm 0.17 \mathrm{a}$ & $2.72 \pm 0.16 \mathrm{a}$ \\
\hline & 30 & $1.85 \pm 0.09 \mathrm{a}$ & $1.49 \pm 0.23 \mathrm{ab}$ & $1.08 \pm 0.17 b$ & $0.00 \pm 0.00 \mathrm{c}$ \\
\hline & 40 & $4.18 \pm 0.41 \mathrm{a}$ & $0.00 \pm 0.00 \mathrm{~b}$ & $0.00 \pm 0.00 \mathrm{~b}$ & $0.00 \pm 0.00 \mathrm{~b}$ \\
\hline & Total & $1.67 \pm 0.05 \mathrm{~b}$ & $1.68 \pm 0.05 \mathrm{~b}$ & $1.86 \pm 0.17 \mathrm{~b}$ & $2.56 \pm 0.31 \mathrm{a}$ \\
\hline \multirow{5}{*}{$\begin{array}{l}\text { Dormancy } \\
\text { rate }(\%)\end{array}$} & 10 & $0.00 \pm 0.00 \mathrm{~d}$ & $45.31 \pm 1.38 \mathrm{a}$ & $12.04 \pm 1.00 \mathrm{c}$ & $26.22 \pm 1.24 \mathrm{~b}$ \\
\hline & 20 & $47.34 \pm 3.05 \mathrm{a}$ & $49.59 \pm 1.33 \mathrm{a}$ & $42.10 \pm 4.28 \mathrm{a}$ & $23.56 \pm 2.69 b$ \\
\hline & 30 & $44.70 \pm 4.26 \mathrm{a}$ & $52.94 \pm 1.95 \mathrm{a}$ & $18.21 \pm 2.84 \mathrm{~b}$ & $0.00 \pm 0.00 \mathrm{c}$ \\
\hline & 40 & $67.44 \pm 7.67 \mathrm{a}$ & $0.00 \pm 0.00 \mathrm{~b}$ & $0.00 \pm 0.00 \mathrm{~b}$ & $0.00 \pm 0.00 \mathrm{~b}$ \\
\hline & Total & $48.34 \pm 0.07 \mathrm{a}$ & $49.26 \pm 1.29 \mathrm{a}$ & $25.71 \pm 0.63 b$ & $24.85 \pm 1.55 b$ \\
\hline \multirow{5}{*}{$\begin{array}{l}\text { Mortality } \\
\text { rate }(\%)\end{array}$} & 10 & $0.00 \pm 0.00 \mathrm{c}$ & $13.98 \pm 2.88 b$ & $14.32 \pm 3.19 b$ & $21.31 \pm 4.52 \mathrm{a}$ \\
\hline & 20 & $1.21 \pm 0.60 \mathrm{~d}$ & $17.07 \pm 2.39 \mathrm{c}$ & $24.64 \pm 4.65 b$ & $34.09 \pm 1.31 \mathrm{a}$ \\
\hline & 30 & $3.77 \pm 1.13 \mathrm{c}$ & $22.63 \pm 3.32 \mathrm{~b}$ & $56.86 \pm 2.93 \mathrm{a}$ & $0.00 \pm 0.00 \mathrm{~d}$ \\
\hline & 40 & $9.77 \pm 1.31 \mathrm{a}$ & $0.00 \pm 0.00 \mathrm{~b}$ & $0.00 \pm 0.00 \mathrm{~b}$ & $0.00 \pm 0.00 \mathrm{~b}$ \\
\hline & Total & $3.51 \pm 0.69 \mathrm{c}$ & $17.78 \pm 1.55 \mathrm{~b}$ & $30.77 \pm 1.67 \mathrm{a}$ & $28.21 \pm 2.45 \mathrm{a}$ \\
\hline
\end{tabular}

From a to $d$, the significance of the difference gradually strengthened $(\mathrm{p}<0.05)$.

After long-term mulching, bamboo bud storage and dormancy rates decreased, bud-output and mortality rates increased, and bud-input rate also increased, but maximum input rate was smaller than that of bamboo forests where no-mulching was practiced. Bamboo mulching broke the dormancy of rhizome lateral buds, causing high intensity bud-output from the bud bank, and this was directly related to the high shoot yield and great economic benefits of mulching in bamboo 
forests. Therefore, it is necessary to increase bud-input and to reduce bud-output for the recovery of declining bamboo forest populations.

\section{Acknowledgments}

This project was financially supported by the Fundamental Research Funds for the Central Non-profit Research Institution of CAF (CAFYBB2017MB030), Zhejiang Province-Chinese Academy of Forestry cooperative project (2017SY02), Science and Technology Planning Project of Zhejiang Province (2014F10047).

\section{References}

Benson EJ, Hartnett DC and Mann KH 2004. Belowground bud banks and meristem limitation in tallgrass prairieplant populations. Am. J. Bot. 91: 416-421.

Dalgleish HJ and Hartnett DC 2009. The effects of fire frequency and grazing on tallgrass prairie productivity and plant composition are mediated through bud bank demography. Plant Ecol. 201: 411-420.

Gui R, Sun X and Zhuang S 2013. Soil acidification in Phyllostachys praecox f. preveynalis cultivation with intensive management. Commun. Soil Sci. Plan. 44: 3235-3245.

Guo Z, Chen S, Yang Q, Li Y and Zhuang M 2014. Effects of mulching management on soil and foliar C, N and P stoichiometry in bamboo (Phyllostachys violascens) plantations. J. Trop. For. Sci. 26: 572-580.

Hartnett DC, Setshogo MP and Dalgleish HJ 2006. Bud banks of perennial savanna grasses in Botswana. Afr. J. Ecol. 44: 256-263.

Hogg EH and Lieffers VJ 1991. Seasonal changes in shoot regrowth potential in Calamagrostis canadensis. Oecologia 85: 596-602.

Jiang PK, Xu QF, Xu ZH and Cao ZH 2006. Seasonal changes in soil labile organic carbon pools within a Phyllostachys praecox stand under high rate fertilization and winter mulch in subtropical China. Forest Ecol. Manag. 236: 30-36.

Jiang P, Ye Z and Xu Q 2002. Effect of mulching on soil chemical properties and enzyme activities in bamboo plantation of Phyllostachy praecox. Commun. Soil Sci. Plan. 33: 3135-3145.

Klimes J 2007. Bud banks and their role in vegetative regeneration - a literature review and proposal for simple classification and assessment. Perspect. Plant Ecol. 8: 115-129.

Ott JP and Hartnett DC 2015. Bud bank dynamics and clonal growth strategy in the rhizomatous grass, Pascopyrum smithii. Plant Ecol. 216: 395-405.

Qian J, Wang Z, Klimešová J, Lü X, Kuang W, Liu Z and Han X 2017. Differences in below-ground bud bank density and composition along a climatic gradient in the temperate steppe of northern China. Ann. Bot. 120: 755-764.

Russell ML, Vermeire LT, Ganguli AC and Hendrickson JR 2015. Season of fire manipulates bud bank dynamics in northern mixed-grass prairie. Plant Ecol. 216: 835-846.

Vesk PA and Westoby M 2004. Funding the bud bank: a review of the costs of buds. Oikos106: 200-208.

Xu M, Zhuang S and Gui R 2017. Soil hypoxia induced by an organic-material mulching technique stimulates the bamboo rhizome up-floating of Phyllostachys praecox. Sci. Rep. 7: 14353.

$\mathrm{Xu} \mathrm{Q}$, Jiang $\mathrm{P}$ and $\mathrm{Xu} \mathrm{Z}$ 2008. Soil microbial functional diversity under intensively managed bamboo plantations in southern China. J. Soil. Sediment 8: 177-183. 